\title{
Pendekatan Saintifik dalam Pembelajaran Seni Tari di SMA Negeri 2 Semarang
}

\author{
Desi Kusuma Sari \\ Alumni mahasiswa Jurusan Sendratasik, Fakultas Bahasa dan Seni, Universitas \\ Negeri Semarang \\ desykoesumasari@yahoo.co.id
}

\begin{abstract}
Abstrak
Pendekatan Saintifik adalah pendekatan pembelajaran yang berorientasi guna membina kemampuan siswa memecahkan masalah melalui serangkaian aktivitas yang menuntut kemampuan berpikir kritis, berpikir kreatif, dan berkomunikasi dalam upaya meningkatkan pemahaman siswa. Rumusan Masalah dalam penelitian ini adalah bagaimana proses pendekatan saintifik dalam pembelajaran seni tari di SMA Negeri 2 Semarang. Tujuan penelitian ini adalah mendiskripsikan proses pendekatan saintifik dalam pembelajaran seni tari di SMA Negeri 2 Semarang. Metode yang digunakan adalah metode kualitatif. Teknik pengumpulan data yang digunakan yaitu observasi, wawancara, dan dokumentasi. Analisis data yang dilakukan yaitu reduksi data, penyajian data, dan penarikan kesimpulan. Sasaran penelitian ini adalah siswa kelas X Mipa 8. Hasil penelitian proses pembelajaran pendekatan saintifik meliputi tiga langkah yaitu Kegiatan Pendahuluan didalamnya terdapat kegiatan apersepsi. Kegiatan Inti didalamnya terdapat Kegiatan Mengamati, Menanya, Mencoba, Menyimpulkan, dan Mengkomunikasikan. Kegiatan Penutup didalamnya terdapat evaluasi pembelajaran dan menyimpulkan hasil pembelajaran.
\end{abstract}

Kata Kunci : Pendekatan Saintifik dan Pembelajaran

\section{PENDAHULUAN}

Pendidikan merupakan proses
kegiatan belajar mengajar,
pengetahuan dan keterampilan yang
dilaksanakan dalam kegiatan formal
untuk mencapai tujuan pendidikan.
Kegiatan formal pendidikan ini di
dalamnya harus melibatkan guru,
murid, kurikulum, metode mengajar,
strategi mengajar dan variabel lainnya

yang bersangkutan. Secara umum, pendidikan ditandai dengan pihak yang memberi dan menerima pengetahuan, nilai, dan kemampuan. Melalui pendidikan anak dapat mengembangkan aspek kognitif, afektif, dan psikomotorik yang di miliki. Guru di dalam hal ini mempunyai peran yang sangat penting untuk menerapkan metode dan 
pendekatan pembelajaran yang tepat di dalam kelas.

Pendidikan di dalamnya
terdapat elemen-elemen bertujuan untuk mendukung suatu pendidikan, seperti adanya kurikulum, pembelajaran, model, strategi, teknik dan segala sesuatu yang membantu berlangsungnya suatu pendidikan. Demikian juga dengan pendidikan seni tari yang diajarkan di sekolah-sekolah. Pendidikan seni tari mencapai tujuan pendidikan melalui pengenalan terhadap budaya tari dengan penguasaan tari-tari lokal ataupun tarian yang ada di Nusantara. Oleh karena itu perubahan dan perkembangan pendidikan adalah hal yang memang seharusnya terjadi sejalan dengan perubahan kebudayaan kehidupan.

Kurikulum yang diterapkan di Indonesia pada tahun 2006 adalah Kurikulum Tingkat Satuan Pendidikan (KTSP). Kemudian pada tahun pelajaran 2013 pemerintah memberlakukan kurikulum baru yang disebut dengan Kurikulum 2013. Kurikulum 2013 untuk mata pelajaran seni tari kelas $\mathrm{X}$ di SMA N 2 Semarang menggunakan pendekatan saintifik. Pendekatan saintifik atau ilmiah, siswa dapat mencapai penguasaan berbagai kompetensi yang meliputi kompetensi sikap, keterampilan, dan pengetahuan. Kurikulum 2013 menuntut siswa aktif dan paham materi, berdiskusi, dan presentasi serta memiliki sopan santun.

Pembelajaran adalah proses interaksi antara siswa dengan pendidik dan sumber belajar pada suatu lingkungan belajar (UU Sisdiknas No.
20 tahun 2013). Dalam Standar Proses (PP No.19 pasal 19 tahun 2005), bahwa proses pembelajaran pada satuan pendidikan diselenggarakan secara interaktif, inspiratif, menyenangkan, menantang, memotivasi siswa untuk berpartisipasi aktif serta memberikan ruang yang cukup bagi prakarsa, kreativitas dan kemandirian sesuai dengan bakat, minat, dan perkembangan fisik, serta psikologis siswa.

Pendekatan pembelajaran adalah suatu proses atau perbuatan yang digunakan guru untuk menyajikan bahan pelajaran (Hosnan 2014:32). Salah satu pendekatan pembelajaran yang diterapkan didalam pembelajaran Kurikulum 2013 adalah pendekatan saintifik. Pendekatan saintifik dimaksudkan untuk memberikan pemahaman kepada siswa dalam mengenal, memahami berbagai materi, bahwa informasi bisa berasal dari mana saja, kapan saja, tidak bergantung pada informasi searah dari guru.

Proses pembelajaran pendekatan saintifik yang menerapkan kemampuan siswa untuk aktif dan kreatif yang didukung menggunakan sarana serta mengikuti mekanisme yang telah diatur dengan baik dalam RPP. Proses pembelajaran yang telah direncanakan dengan baik akan mencapai tujuan yang telah ditetapkan. Selain menerapkan proses pembelajaran yang telah ditata dengan baik, juga harus selalu ada timbal balik dan melakukan kajian untuk terus membenahi proses pembelajaran. SMA Negeri 2 Semarang merupakan salah satu sekolah negeri di Kota 
Semarang yang menerapkan kurikulum 2013.

Pembelajaran seni adalah suatu proses usaha yang dilakukan seseorang untuk memperoleh suatu perubahan sikap dan tingkah laku sebagai hasil pengelaman berkesenian dan berinteraksi dengan budaya lingkungan untuk sampai tujuan tertentu. Tiga prinsip pembelajaran seni adalah: (1) Pembelajaran seni di sekolah harus memberikan kebebasan pada diri siswa untuk mengolah potensi kreatifnya, (2) Pembelaharan seni di sekolah harus dapat memperluas pergaulan dan komunikasi siswa dengan lingkungannya, (3) Pembelajaran seni di sekolah hendaknya dilakukan dengan cara yang menyenangkan dan dalam suasana yang bebas tanpa tekanan (Jazuli 2008:39).

\section{METODE PENELITIAN}

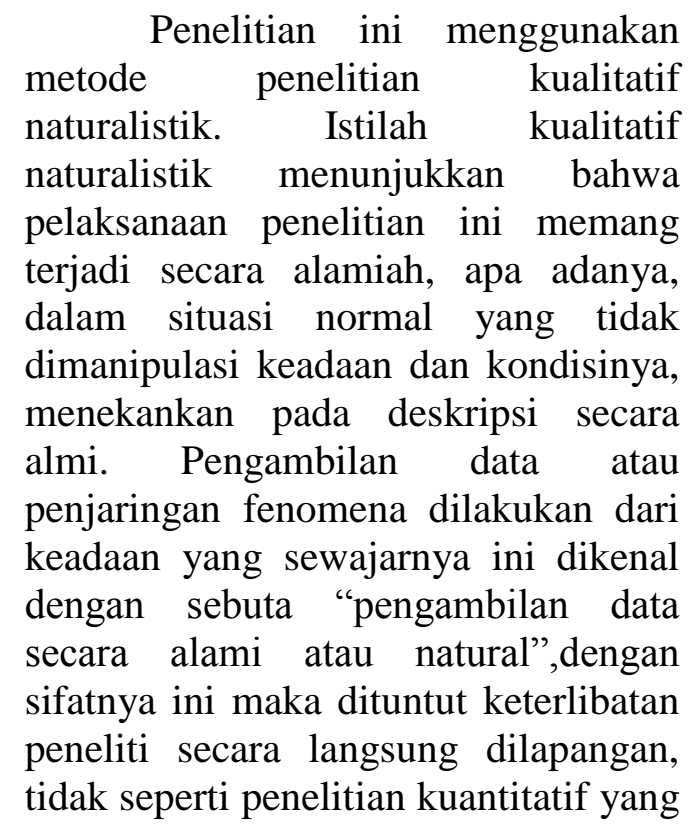

dapat mewakilkan orang lain unutk menyebarkan atau melakukan wawancara terstruktur (Arikunto 2006:12).

Pengambilan data secara alami dan natural dilakukan dengan mendiskripsikan secara apa adanya proses pembelajaran seni tari kelas $\mathrm{X}$ di SMA N 2 Semarang menggunakan pendekatan saintifik yang meliputi sepuluh aspek pembelajaran, yaitu guru, siswa, tujuan, materi, metode, media, proses pembelajaran, sumber belajar, evaluasi, sarana prasarana, dan juga perangkat pembelajaran meliputi program tahunan, program semester, silabus,dan RPP yang telah dibuat oleh guru seni tari.

Sasaran penelitian ini adalah bagaimana proses pendekatan saintifik dalam mata pelajaran Pergelaran Tari di kelas X MIPA 8, salah satu kelas yang dianjurkan oleh Guru Seni Tari, karena dianggap sebagai kelas yang mempunyai antusias tinggi dalam pelajaran Seni Tari diantara kelas yang lain. Sehingga peneliti memutuskan untuk melakukan penelitian di kelas tersebut.

Pelaksanaan pengumpulan data dilaksanakan dengan menggunakan teknik observasi, wawancara, dan dokumentasi. Analisis data dalam penelitian ini dilakukan sejak awal dan sepanjang proses penelitian berlangsung. Analisis data penelitian lebih ditekankan pada analisis yang digunakan dalam pendekatan etnografi. Dalam penelitian etnografi ini, analisis data lapangan dikumpulkan dari hasil observasi partisipan dan wawancara mendalam ditujukan untuk menemukan 
pertanyaan atau focus penelitian.

Teknik Analisis data yang dikemukakan oleh Milles dan Huberman (dalam Rohidi, 1992:16), data yang diperoleh dengan melalui teknik wawancara, observasi, atau dokumentasi kemudian direduksi, disajikan, selanjutnya disimpulkan dan diverifikasikan. Dalam penelitian ini data yang telah terkumpul dianalisis secara deskriptif. Data tersebut kemudian direduksi (disederhanakan), diklasifikasikan (kelompokan), diinterpretasikan, dan dideskripsikan ke dalam bentuk bahasa verbal untuk mencari verifikasi (penarikan kesimpulan).

Yin (2003: 56) mengajukan empat kriteria teknik keabsahan data yang diperlukan dalam suatu penelitian pendekatan kualitatif. Empat hal tersebut ialah: (1) Keabsahan Kontruk, (2) Keabsahan Internal, (3) Keabsahan Eksternal, (4) Keajegan (reabilitas). Penelitian ini menggunakan teknik pemeriksaan triangulasi yaitu teknik data yang memanfaatkan sesuatu yang lain dari luar data itu untuk keperluan pengecekan atau sebagai pembanding terhadap data itu (Moleong 2010:195).

\section{HASIL PENELITIAN}

Pendekatan Saintifik dalam pembelajaran seni tari di SMA Negeri 2 Semarang meliputi persiapan dan pelaksanaa. Persiapan meliputi pembuatan Silabus dan Rencana Pelaksanaan Pembelajaran (RPP). Pelaksanaan pembelajaran meliputi sepuluh komponen pembelajaran yaitu (1) Guru, (2) Peserta didik, (3) Tujuan,
(4) Bahan pelajaran, (5) Kegiatan pembelajaran, (6) Metode, (7) Alata/Media, (8) Sumber pembelajaran, (9) Evaluasi, dan (10) Sarana dan Prasarana.

Guru adalah pelaku pembelajaran, sehingga dalam hal ini guru merupakan faktor yang terpenting. Tangan guru merupakan letak keberhasilan pembelajaran. Komponen guru tidak dapat dimanipulasi atau direkayasa oleh komponen lain, dan sebaliknya guru mampu memanipulasi atau merekayasa komponen lain menjadi bervariasi. Proses belajar mengajar, guru mempunyai tugas untuk mendorong, membimbing, dan memberi fasilitas belajar bagi siswa untuk mencapai tujuan. Peserta didik atau siswa merupakan komponen yang melakukan kegiatan pembelajaran untuk mengembangkan potensi kemampuan menjadi nyata untuk mencapai tujuan pembelajaran.

Tujuan pembelajaran seni tari menggunakan pendekatan saintifik menjadikan siswa lebih aktif dan kreatif dalam pembelajaran. Tujuan pembelajaran pada kurikulum 2013 yang menggunakan pendekatan saintifik, terdapat secara jelas tujuan pada ranah sikap, sosial, pengetahuan, dan keterampilan (Permendikbud no.68 th 2013). Tujuan dalam ranah sikap yaitu siswa mampu menghayati dan mengamalkan serta bangga terhadap karya tari sebagai bentuk rasa syukur terhadap Anugerah Tuhan. Tujuan ranah sosial adalah siswa mampu menghargai dan menghayati perilaku kerja sama, bertanggung jawab, toleran, dan disiplin melalui 
aktivitas berkesenian. Tujuan dalam ranah pengetahuan dan keterampilan adalah setelah pembelajaran peserta didik mampu: (1) Memahami pengertian pergelaran karya tari, (2) Memahami teknik dan prosedur pergelaran karya tari, (3) Mengidentifikasi teknik dan prosedur pergelaran seni tari, (4) Memahami hubungan cabang seni tari dengan cabang seni lainnya, (5) Mengidentifikasi unsur pendukung pergelaran karya tari, (6) Mengkomunikasikan pergelaran karya seni tari, (7) Melakukan pergelaran seni tari.

Bahan pelajaran untuk kelas $\mathrm{X}$ Mipa 8 semester genap tahun ajaran 2015/2016 adalah pergelaran karya tari. Pergelaran karya seni tari merupakan pertunjukan atau penyajian tari yang ditujukan kepada orang lain atau penonton. Pergelaran tari di sekolah menjadi proses belajar siswa dalam mengekspresikan pikiran dan perasaannya serta keterampilan dan bakat lewat gerak.

Kegiatan belajar mengajar pembelajaran seni tari terdiri dari tiga langkah yaitu Kegiatan Pendahuluan yang dilaksanakan yaitu menyiapkan peserta didik secara fisik dan psikis untuk mengikuti proses pembelajaran, mengajukan pertanyaan-pertanyaan yang berkaitan dengan pengetahuan sebelumnya dengan materi yang akan dipelajarai, menjelaskan tujuan pembelajaran dan kompetensi dasar yang akan dicapai, menyampaikan cakupan materi dan penjelasan uraian kegiatan sesuai silabus. Kegiatan Pendahuluan dilakukan setelah semua siswa memasuki ruang kelas. Seluruh siswa duduk di tempat duduk masingmasing. Guru mengucapkan salam dan dijawab serentak oleh peserta didik, kemudian guru menginformasikan materi yang akan dipelajari. Seluruh siswa menhadap guru dan memperhatikan serta mendengarkan penjelasan secara seksama.

Kegiatan Inti dalam pembelajaran seni tari kelas X Mipa 8 yaitu menggunakan pendekatan saintifik meliputi: Kegiatan Mengamati, guru memfasilitasi peserta didik untuk melakukan pengamatan, melatih siswa untuk memperhatikan (melihat, membaca, mendengar) hal yang penting dari suatu benda atau objek. Kegiatan Mengamati diawali dengan guru meminta siswa membuka buku paket seni budaya, membaca dan mengamati tentang materi pergelaran seni tari dan mengamati video untuk menambah wawasan tentang pergelaran sendratari.

Kegiatan Menanya, guru membuka kesempatan secara luas kepada peserta didik untuk bertanya mengenai apa yang dilihat, disimak, dibaca atau dilihat. Kegiatan Menanya dilakukan dengan guru menanyakan hal-hal yang berkaitan deng Pergelaran Seni Tari, unsur dan pendukung pergelaran sni tari, dan prosedur pergelaran seni tari, selain itu guru juga menanyakan persiapan dalam pembuatan pergelaran tari.

Kegiatan Mencoba atau mengeksplorasi, guru memberikan kesempatan siswa untuk bereksplorasi gerak. Kegiatan Mencoba atau mengeksplorasi dilakukan denga cara guru meminta peserta didik untuk berkumpul dan berkelompok masing- 
masing seksi dalam menyiapkan sebuah kepanitiaan pergelaran. Kegiatan Mencoba dilakukan dengan guru memberikan waktu kepada peserta didik untuk berdiskusi, pembentukan panitia pergelaran sampai pembuatan proposal pergelaran, guru mendampingi peserta didik dan terus memantau proses peserta didik mencoba atau bereksplorasi.

Kegiatan Menyimpulkan yaitu peserta didik dapat menghargai pendapat orang lain, menerapkan kemampuan mengumpulkan informasi dan kemampuan berkomunikasi. Kegiatan tersebut terkumpul sejumlah informasi yang menjadi dasar bagai kegiatan berikutnya yaitu memproses informasi untuk menemukan keterkaitan satu informasi dengan informasi lainnya dan mengambil berbagai kesimpulan. Kegiatan Menyimpulkan dilakukan bersama dengan guru untuk mengambil kesimpulan dari masalah yang telah peserta didik diskusikan bersama. Penyusunan proposal kegiatan dan persiapan pergelaran seni tari. Kemudian pada tahap selanjutnya guru membantu siswa untuk menyimpulkan gerakan-gerakan tari yang telah dilakukan pada tahap ekplorasi atau mencoba.

Kegiatan Mengkomunikasikan hasil yaitu peserta didik menuliskan atau menceritakan apa yang ditemukan dalam kegiatan mencari informasi, mengasosiasikan dan menemukan hasil yang akan disampaikan. Kegiatan Mengkomunikasikan hasil dilakukan dengan guru meminta salah satu sebagai ketua, sutradara pergelaran seni tari di kelas $\mathrm{X}$ Mipa 8 untuk menjelaskan hasil yang diperoleh dan disepakati bersama di kelas tersebut. Hasil tersebut disampaikan di kelas dan dinilai oleh guru sebagai hasil belajar peserta didik atau kelompok peserta didik tersebut. Hasil yang disampaikan dalam kegiatan pembelajaran ini adalah pembentukan kepanitian, langkah-langkah pembuatan proposal, dan pemilihan cerita sendratari.

Kegiatan penutup didalamnya terdapat evaluasi pembelajaran dan menyimpulkan hasil pembelajaran, guru bersama-sama dengan peserta didik dan atau sendiri membuat rangkuman atau simpulan pelajaran, melakukan penilaian dan refleksi terhadap kegiatan yang sudah dilaksanakan secara konsisten dan terprogram, memberikan umpan balik terhadap proses dan hasil pembelajaran, merencanakan kegiatan tindak lanjut dalam bentuk pembelajaran.

Metode yang digunakan pada pembelajaran seni tari yaitu Mengamati, Menanya, Mencoba, Menyimpulkan, dan Mengkomunikasikan. Pembelajaran selain metode tersebut, guru juga menggunakan metode penugasan, tanya jawab, diskusi, demonstrasi, proyek, dan ceramah. Media pembelajaran yang digunakan guru pada pembelajaran seni tari semester genap dengan materi pergelaran karya tari adalah gambar, video, dan pertunjukan sendratari ramayana secara langsung.

Evaluasi yang dilakukan dalam pembelajaran seni tari meliputi 
penilaian pengetahuan, sikap, dan keterampilan. Guru selalu menilai siswa pada setiap pertemuan yang meliputi sikap siswa, pengetahuan siswa dan bertanya pada siswa, keterampilan siswa dilihat pada saat siswa mengkomunikasikan dalam bentuk praktik hasil diskusi.

\section{KESIMPULAN}

Kegiatan Pendahuluan di dalamnya terdapat kegiatan apersepsi, guru menyiapkan persiapan peserta didik secara fisik dan psikis untuk mengikuti proses pembelajaran. Kegiatan Inti di dalamnya terdapat (1) Kegiatan Mengamati, guru memfasilitasi peserta didik untuk melakukan pengamatan, melatih siswa untuk mengamati, (2) Menanya, guru memberikan kesempatan secara luas kepada peserta didik untuk bertanya mengenai apa yang dilihat, dibaca, dan disimak, (3) Mencoba, guru memberikan kesempatan secara luas kepada peserta didik untuk bereksplorasi, (4) Menyimpulkan, peserta didik dapat menghargai pendapat orang lain, menerapkan kemampuan mengumpulkan informasi dan kemampuan berkomunikasi, dan (5) Mengkomunikasikan hasil, peserta didik menuliskan, menceritakan atau memperagakan yang ditemukan dalam kegiatan mengumpulkan informasi. Kegiatan Penutup di dalamnya terdapat evaluasi pembelajaran dan menyimpulkan hasil pembelajaran, guru bersama-sama dengan peserta didik dan atau sendiri membuat rangkuman dan simpulan pelajaran.

\section{DAFTAR PUSTAKA}

Arikunto, Suharsimi. 2006. Prosedur Penelitian Suatu Pendekatan Praktik. Jakarta:Rineka Cipta.

Astini, S., \& Utina, U. (2011). TARI PENDET SEBAGAI TARI BALIH-BALIHAN ( Kajian Koreografi) (Pendet Dance as Welcome Dance Coreography Research). Harmonia: Journal Of Arts Research And Education, $8(2)$. doi:http://dx.doi.org/10.15294/ harmonia.v8i2.789

Utina, U. (2011). PEMBELAJARAN TARI BERKONTEKS TEMATIK BERDASARKAN KURIKULUM BERBASIS KOMPETENSI DI TK PEMBINA SINGOROJO KABUPATEN KENDAL. Harmonia: Journal Of Arts Research And Education, 9(1). doi:http://dx.doi.org/10.15294/ha rmonia.v9i1.675

Utina, U. (2011). PEMBELAJARAN TARI BERKONTEKS TEMATIK BERDASARKAN KURIKULUM BERBASIS KOMPETENSI DI TK PEMBINA SINGOROJO KABUPATEN KENDAL. Harmonia: Journal Of Arts Research And Education, 9(1). doi:http://dx.doi.org/10.15294/ harmonia.v9i1.675

Hosnan, M. 2014. Pendekatan Saintifik dan Kontekstual dalam Pembelajaran Abad 21. Bogor: Ghalia Indonesia.

Huberman, Milles, A.M. 1992. Terjemah T. Rohendi Rohidi. Analisis Data 
Kualitatif. Jakarta: Permendiknas no. 19.2005. Standar

Universitas Indonesia

Jazuli,M. $2008 . \quad$ Paradigma

Kontekstual Pendidikan

Nasional Pendidikan.

Jakarta: Mendikbud RI

Seni. Semarang: Unesa

University Press.

Moleong, 2010. Metodologi Penelitian

Kualitatif. Bandung: PT

Remaja Rosda Karya.

Permendikbud no. 65. 2013. Standar

Proses Pendidikan Dasar

dan Menengah. Jakarta:

Mendikbud RI 